研究課題別評価

1. 研究課題名：脳のセグメン構造に基づくパラレルプロセッシング

2. 研究者氏名：小田 洋一

3. 研究の狙い:

生物が進化の過程で脳(集中神経系)を獲得したときから,脳は分節(セグメント構造をなしてい る.最も原始的なホヤ幼生の単体節神経系からナメクジウオの多体節神経系になったときに起こ つた基本構造の重複と変異こ光が,脳の進化の出発点であり,このプロセスは哺乳動物まで保存 される.脳が分節構造をとつたことが,脳の機能原理にも重要な方向を与えたのではないだろう か?

硬骨魚の後脳にある網樣体脊髄路(RS)二ューロン群は明確な分節構造を保ち,ゼブラフィツシ ユやキンギョでは約30種のRSニューロンが総数約200個存在する.さらに,形態学的によく似た相 同RS二ューロンが隣接する分節に繰り返されるという,興味深い配列を示す.最大の大きさをも つマウスナー(M)細胞が魚の逃避運動をトリガ一することが古くら知られていた.本研究では,M 細胞と相同RS二ューロンが互いにどのような電気生理学的特性を持つか，どのような入力投射を 受けるか, 相互にどのような結合をつくっているか，つくられた後脳RS二ューロン回路は魚の逃避 運動の制御にどのような役割を果たすかを調べて,脳の分節構造が脳の機能獲得に果たす役割 を理解しようとした .

4. 研究結果 :

(1)分節構造を反映した脳二ューロンの機能分化と機能結合

キンギョの後脳第4 6 分節に存在する形態学的に相同のRSニューロンが, 共通の感覚神 経投射を受けながら異なる電気特性を示し,さらに分節構造を反映した相互結合を持つこと を見出した。

(a)聴神経(VIII 神経)から分節への投射

聴神経から第4分節のM細胞と第5-6分節の相同RSニューロンへの興奮性結合を電気生 理学的に明らかにした .さらにOregon Green Dextranで逆行性ラベルしたRNニューロンとDil で順行性にラベルした聴神経の蛍光像から,聴神経がこれらのニューロン群へ投射すること を形態学的にも確かめた.興味深いことに，聴神経が脳幹に一樣に投射するのではなく,聴 神経の求心線維束も分節をなし, 各分節のRSニューロンの樹状突起近傍に局在していた .

(b) M細胞と相同ニューロンの異なる発火特性

魚の逃避運動をトリガ一するM細胞は単発の活動電位しか発生しない.この特異的な興奮 性は,M細胞の膜の電位依存性カリウムチャネルとM細胞特有の反回性抑制によって達成さ れていることを示した.一方,第5-6分節のRNニューロンは膜電位に対応した発火周波数で バースト放電することが明らかにされた.すなわち，入力に対してM細胞は全無的, 相同RS二 ユーロンはアナログ的に応答すると解釈された .

(c) 分節に繰り返される相同ニューロン間の機能結合

M 細胞とRSニューロンの同時記録から,相同ニューロン間の機能結合を見出した .結合は 第4分節のM細胞から第5-6分節の相同ニューロンへ一方向のみで, 逆方向の結合は存在 
しない.さらに 結合のパターンが形態学的分類にしたがうことを明らかにした .すなわち背側 の存在するMiD群へはM細胞から抑制性結合,腹側に存在するMiV群には興奮性結合であつ た.しかもM細胞から第5分節のMiDやMiVへの結合樣式は第6分節でも保たれており,分節構 造と光の中で起こる細胞分化を反映した投射樣式が浮かび上がってきた .脳の分節構造は 発生学的な研究か数多〈なされているが, 機能的な結合樣式に踏み込んだものは初めてで ある。

(2)抑制性シナプス応答のカルシウム・イメージング

生体内での抑制性シナプス応答を世界にさきがけて光学計測することに成功した .分節に またがって形成された脳回路の動態を調べるには従来の微小電極法に加えて,ニューロン群 の並列活動をイメージングする光学計測が有力な手段である.しかし,従来のイメージングは 興舊性応答のみに限られており，脳回路の制御に重要な役割を果たす抑制性シナプス応答 を計測した例はなかった .われわれはM細胞では抑制性シナプスコンダクタンスによって活動 電位の振幅が小さくなる点に着目し,活動電位の振幅にしたがったカルシウム流入を共焦点 レーザー顕微鏡を用いて抑制性シナプス応答を初めて光学計測した .このシステムによって 抑制性結合も含めたニューロン間の相互作用を無傷の動物から記録 非侵襲計測)する道が 開かれた .

5. 自己評価 :

硬骨魚の後脳分節に繰り返される網樣体脊髄路二ューロンを研究対象にして,弾の分節構 造に基ついた機能構築を研究しようとした本研究計画は,脳の基本構造を見据えて脳の機能 発現を理解しようとするものであると自負している.分節間相同ニューロンの相互結合に関し ては ,複数の二ューロンからの同時細胞内記録と形態学的同定を地道におこない当初の目 的をほぼ羍成した.機能分化の典型としてとらえたマウスナー(M)細胞の独特の発火特性が $M$ 細胞特有の反回性(フィードバック)抑制のほか電位感受性低閾值型カリウムチャネルによ ることまてつきとめられ，機能分化に関して予想を超える成果を得た .また，今まて取り組まな かつた形態学的な解析を積極的に取り入れることによって, 分節構造を反映した感覚神経投 射をはじめて見出せた成果も予想を超えていた .

分節に従って機能分化し相互に機能結合している網樣体脊髄路ニューロンの並列活動を 観察できる光学計測システムを当初の計画通り完成した.従来のイメージングシステムでは ニューロンの興奮だけを計測しているが, 本研究ではニューロンの動特性の制御に重要な抑 制性シナプス応答をも光学計測でき, 発表論文は国際的に評価された.逃避運動中の二ュー ロン群の活動に関しては, 魚の運動と脳内ニューロン活動を同時計測するシステムの構築ま でを達成できた。

以上のように，研究全般にわたつて独自に計画し実行したために他に例を見ないユニーク な成果を得られた反面，機能分化の分子生物学的解析など共同研究をすれば進むであろう 側面に関しては展開されなかった .しかしながら, 私は自分自身の興味と地に足が付いた理 解を好むので,この 3 年間の研究成果を喜んでいる.

6. 研究総括の見解 :

金魚の巨大なマウスナー神経細胞を用いて、脳神経系の原始的な分節構造と機能を独自 の方法論を駆使して解明した生理学的研究として大いに評価される。独創的なよく考え抜か 
れた研究で、海外からも基礎的な貢献として注目されている。

\section{7. 主な論文等：}

\section{(1)論文}

Komatsu H., Murayama Y., Iwaki T., T sukamoto I., Ogli K. and Oda Y. Effects of enflurane on the long- term potentiation in the hippocampus. Prog. Anesth. Mech., 6: 515- 518, 2000

Takahashi M., Narushima M. and Oda Y. In vivo imaging of functional inhibitory networks on the Mauthner cell of larval zebrafish. J J Neurosci. 22: 3929- 3939, 2002

Nakayama, $\mathrm{H}$. and Oda, Y. Functional organization of segmentally homologous reticulospinal neurons in goldfish hindbrain (submitted)

Nakayama, $\mathrm{H}$. and Oda, Y. Common synaptic drive from the Mauthner cell to segmentally homologous reticulospinal neurons in the teleost hindbrain (submitted)

\section{(2)総説 解説}

Oda, Y. LTP Clinical Neuroscience, 17(7): 107, 1999

小田洋一 LTP解析法 ヒリーズ 論文理解のためのニューロサイエンス研究法) 脳の科学， 21(7): 743-749, 1999

小田洋一 日本の脳研究者たち 塚原仲晃」Brain Medical, 11: 102- 105, 1999

小田洋一 学習を担うシナプス伝達の長期増強 蛋白質 核酸 酵素」増刊号 神経回路 形成と機能発達」464 473, 2000

小田洋一＼cjkstart記憶のメカニズム 脳21,3(2): 258 264, 2000

小田洋一 学習を担うシナプス伝達の長期増強 蛋白質 核酸 酵素」増刊号 神経回路形 成と機能発達」464 473, 2000

小田洋一 脳の可塑性のメカニズム 認知科学の新展開 䡎敏郎 安西祐一郎編)第1 巻 認 知発達と進化」pp.144 163 ,岩波書店, 2001

小田洋一 学習 記憶を担うシナプス長期増強 生物物理 41:80-85, 2001

小田洋一,中山寿子 逃避運動の制御と可塑性のメカニズム＼cjkstart魚の二ューロサイエンス」(植 松一眞 岡良隆 伊藤博信編) pp. 22- 37, 恒星社厚生閣, 2002

小田洋一,中山寿子 聴覚 脳 神経科学入門講座 渡辺雅彦編) pp. 117- 130, 羊土社, 2002

\section{(3)口頭発表}

\section{国際会議}

Oda, Y. Inhibitory long- term potentiation underlies auditory conditioning of goldfish escape behavior. Interface between System Brain Science and Neuroethology September 23-26, 1999, Sendai

Oda, Y., Nakayama, H., Matsui, H. and Murakami, Y. Functional organization of segmentally homologous reticulospinal neurons in teleost hindbrain. 29th Annual Meeting of the Society for Neuroscience October 23-28, 1999, Miami (U.S.A.)

Oda, Y. Inhibitory Networks of the Mauthner Cell in Goldfish and Zebrafish. Interface between System Brain Science and Neuroethology. October 30-November 1, 2001, Okazaki 


\section{国内学会}

招待講演

小田洋一 逃避運動の学習をになう後脳ニューロンの LTP 第 22 回神経科学学会 イブニン グフォーラム 記憶学習のシナプス可塑性と脳内システムの接点」1999年 7月 6〜8日 大阪) 小田洋一 魚の逃避運動を制御する後脳セグメン間相同ニューロンの機能分化と機能結合 第 78 回日本生理学会 シンポジウム 神経回路による特徵抽出のメカニズム」2001年 3 月 29 ３1日 京都)

小田洋一 逃避運動の学習をになう抑制性シナプスの長期増強 第 24 回日本分子生物学会 シンポジウム 神経可塑性の分子的基盤」2001 年 12 月 9〜12日 横浜)

一般講演発表 8 件 